\title{
Measuring Carefully: Validating the International Posture-Child Instrument
}

\author{
James A. Elwood \\ Meiji University \\ Naoko Monoi \\ Chiba University
}

With the onset of English education in elementary schools in Japan mandated at an earlier age than in the past, the need to understand the extent to which children obtain international posture (Yashima, 2002) has become increasingly crucial. Toward that end, in the current study a validation of the International Posture-Child instrument (Monoi-Yamaga, 2010 ; Yamaga, 2007) precedes an investigation of the configuration and level of International Posture that 5th- and 6th-grade students at 5 Japanese public elementary school students possessed. Results indicated that configurations of children differed from that of adults, with 5 th graders exhibiting a 2 -factor configuration and 6th graders either an identical 2-factor configuration or a more complex 3-factor structure. Using the 2-factor configuration, levels of International Posture of the 5 th and 6 th graders were found to be statistically indiscernible. Implications and suggestions for further research are discussed.

日本の公立小学校における英語教育(外国語活動)が必修化されたことに伴い、児童が国際 的志向性 (Yashima, 2002)を有する程度を把握する必要性がますます高まっている。そのた め、本研究では児童用国際的志向性測定尺度（Monoi-Yamaga, 2010 ; Yamaga, 2007)の妥当性 を確認し、その後、5つの公立小学校に在籍する5，6年生の国際的志向性の構造及びその值を 調査した。その結果、児童のもつ国際的志向性の構造は大人のそれとは異なること、具体的に は、5年生が2因子の下位構造、6年生は2因子ないしはより複雑な3因子の下位構造であること が明らかになつた。5,6年生の有する国際的志向性がともに2因子構造であるとして比較分析を 行った結果、その数值に統計的な有意差は見られず、学年によって数值に差がみられないこと が確認された。この結果を踏まえ、今後の研究への示唆について議論する。

JALT Journal, Vol. 37, No. 2, November 2015 
In April of 2011 the grade at which students begin formal English education in school in Japan was lowered to fifth from seventh. Weekly English lessons (Foreign Language Activities ${ }^{1}$ ) were begun in earnest with 35 lessons a year in all fifth- and sixth-grade classrooms (Ministry of Education, Culture, Sports, Science and Technology [MEXT], 2008). This move was widely supported among parents of elementary-age children (Benesse Educational Research and Development Center, 2007a), yet elementary school teachers expressed concerns about conducting English lessons on a regular basis (Benesse Educational Research and Development Center, 2007b). Among the concerns raised were inadequate foreign language teaching skills and infrequent inservice training or workshops to improve those skills (MEXT, 2012).

Nonetheless, this ambitious plan was implemented and has now been in place for 4 years. Although mastery of English was not among the objectives included, the idea of fostering "a positive attitude toward communication" was clearly stated (MEXT, 2008, p. 1). The exact meaning of positive attitude remains somewhat nebulous, yet research has delved into other affective variables for young learners, including such areas as motivation and communication apprehension (e.g., Kunimoto, 2005, 2006; Matsumiya, 2005, 2006; Nishida, 2011, 2012; Nishida \& Yashima, 2009). Studies addressing positive attitude, however, remain relatively scarce. One concern in the current situation is that many researchers have created their own instrument (or their own translation of an instrument) to measure such variables, yet the psychometric properties of those instruments have not necessarily been well researched.

In this study, the authors focus on International Posture (hereinafter, IP; Yashima, 2002) as a proxy for positive attitudes and one affective facet of young learners. Two aspects of these will be addressed: the validation of an instrument to measure elementary school students' IP and the extent to which typical Japanese elementary school students exhibit increases in IP after 1 year of Foreign Language Activities. The results will provide insight into the structure of the IP of young Japanese students and whether the level of IP differs in students in different grades. Such results will shed light on the efficacy of the Foreign Language Activities in facilitating the development of IP in elementary school students. Moreover, results will also illuminate whether the continued use of such activities aids students' development of an understanding of languages and cultures and an enhancement of a positive attitude toward communication. 


\section{Literature Review}

This section begins by tracing the evolution of the IP construct, a relatively recent construct, yet one with roots that stretch back some 40 years.

\section{International Posture}

The relatively brief history of the affective construct IP grew out of the work of Robert Gardner and colleagues some 40 years ago yet came to fruition in the work of Tomoko Yashima and colleagues around the turn of the century. Yashima (2002) detailed this new construct as one's "attitude toward the international community" (p. 56). Although earlier work (e.g., Gardner, 1985) had noted how one's relationship toward the target language community played an important role in language acquisition, much of that research dealt with ESL contexts, in which the level of learners' exposure to the target language and interaction with target language speakers are both much higher than in most EFL contexts in Japan. Specifically, learners in Japan have comparatively fewer encounters with English speakers and are thus less likely to have particularly clear images of and knowledge about foreigners. Indeed, such images may well be heavily dependent on media. Thus, one's relationship with foreigners differs from that found in second language contexts.

Thus, a need existed for a complementary concept in foreign language contexts such as those in Japan. Addressing this, in her 2002 study Yashima applied MacIntyre and Charos's (1996) model to formal language learning in universities in one Japanese context to investigate the relationships between IP and other affective variables. Yashima's study provided several positive findings that corroborated those of MacIntyre and Charos. Among those findings were that communication anxiety in the $\mathrm{L} 2$ and perceived communication competence in L2 predicted measured L2 communication confidence, which in turn predicted L2 willingness to communicate (WTC) to a considerable degree, and that L2 learning motivation directly influenced L2 proficiency, which has a strong connection to frequency of L2 communication. Another important finding in her study was that IP directly influenced both L2 learning motivation and L2 WTC. In that Japanese EFL setting, IP functioned as a key factor for both high school and university students in facilitating increases in language learning motivation, the tendency to freely initiate communication of their own volition, and the major affective variables.

The structure of IP of Japanese university students was found to consist of four constructs (Yashima, 2002). Intercultural Friendship Orientation 
in Learning English addressed whether learners study English in order to communicate with members of the foreign community, and Intergroup Approach-Avoidance Tendency looked at whether learners approach or avoid non-Japanese living in Japan. Interest in International Vocation or Activities focused on actions that entailed either going abroad or being concerned with things abroad. The fourth construct, Interest in Foreign Affairs, addressed interest in news about happenings abroad.

In the interval since its inception, the IP instrument has been extensively studied, yet results concerning its exact configuration have been mixed. In an earlier Yashima study, the additional orientations of academic orientation, travel, music, information, and a "vague sense of necessity" emerged (Yashima, 2000, pp. 125, 127), yet these were excluded from the IP construct that was to be introduced shortly thereafter. Moreover, in her 2002 study, Yashima initially included Ethnocentrism but deleted it based on an inadequate reliability level (pp. 58-59). In later studies (Yashima \& ZenukNishide, 2008; Yashima, Zenuk-Nishide, \& Shimizu, 2004), only three of the original factors were used, with Intercultural Friendship Orientation having been omitted. A different structure was reported by Elwood (2011), who found that IP consisted of just two factors, Intergroup Approach-Avoidance Tendency and Intercultural Friendship Orientation. Moreover, preliminary analyses (Elwood, 2011, pp. 172-178) indicated that Cultural Friendship Orientation could have either one or two dimensions. Ultimately, the best synopsis of the IP construct may well be this: "Included in the [IP] concept, among other things [emphasis added], are Interest in Foreign or International Affairs, Willingness to Go Overseas to Stay or Work, and a Readiness to Interact with Intercultural Partners" (Yashima et al., 2004, p. 125).

Thus, the configuration of the IP construct remains an issue worthy of consideration. To this question we add the requisite consideration of the respondents, most of whom in previous studies have been university-age students with far more life experience and more highly developed personalities than the elementary school students in the current study. Much as such other variables as self-esteem (Block \& Robins, 1993), interest and competency ratings (Tracey, 2002), perceived competence (Harter, 1982), self-concept (Marsh, Barnes, Cairns, \& Tidman, 1984), and intellectual development (Nakazawa \& Ino, 1984) evolve over time in young people, an evolution of IP over time for young learners seems to be a reasonable expectation.

Unfortunately, few IP studies have focused on elementary school students. Among the few that did, in Yamaga (2007) and Monoi-Yamaga (2010), instruments were developed to measure the IP, self-esteem, and collective 
self-esteem of elementary school students. These studies focused more on the relationship of the three affective variables than on the children's conceptualization of IP. Monoi (2013) focused on exploring the configuration of the IP of 10- to 12-year-old children and investigating whether it increased based on their having experienced Foreign Language Activities. Including 496 ten- to twelve-year-old students in three public elementary schools, the focus of the study was mainly on changes of their IP after a 1-year experience of Foreign Language Activities as a language learner. Thus, the study was essential to clarify the configuration of IP in order to better understand the IP construct in young learners, allow accurate measurement thereof, and contribute to the development of a WTC model for young foreign language learners in Japan.

Although limited in number, past studies have shown that the configuration of elementary school children's IP is slightly different from that of high school and university students. In an EFL context, young learners tend to have difficulty developing a clear perception of a certain group to communicate with (Errington, 2009; Yashima, 2002; Yashima et al., 2004) because of their limited life experience. The target person or group will remain rather vague and general because the term foreigners represents outsiders to Japanese children.

Based on a small study of fifth and sixth graders at a public school in Japan, Monoi-Yamaga (2010) found that the composition of the constructs Intercultural Friendship Orientation in English Learning, Intergroup ApproachAvoidance Tendency, and Interest in International Vocation or Activities differed somewhat from those in Yashima (2002), but the remaining factor, Interest in Foreign Affairs, showed a similar configuration. Similar results were found in the Monoi (2013) study, in which IP consisted of four factors: Intercultural Friendship Orientation in English Learning and Daily Life, Intergroup Approach-Avoidance Tendency, Interest in Foreign Affairs, and Affection for Life in Japan. However, the fourth factor was dropped based on low reliability levels. Unlike in earlier studies by Yashima and colleagues (Yashima, 2002; Yashima et al., 2004), Interest in International Occupations or Activities did not emerge as one of the factors in the study. This suggests that elementary school students possess IP, yet the structure is somewhat simpler and more malleable than that of high school students or university students.

The underlying impetus for the current study is the possibility that if Japanese elementary school students learning a language develop positive attitudes toward the international community, their L2 learning motivation 
and L2 WTC will increase. Thus, in the future such positive attitudes could facilitate increased L2 proficiency and frequency of L2 communication. Given this posited sequence of events, the goal of the current study is to investigate the structure of IP in Japanese elementary school students and the extent to which its level and those of its constituent factors differ after one additional year of exposure to Foreign Language Activities.

\section{Instrument Validation}

In light of the ongoing push by MEXT to implement the teaching of foreign languages in elementary schools in Japan, researchers would benefit from an instrument specifically targeting elementary students and capable of yielding reliable, valid information about their acquisition of IP. Therefore, in the current study the IP-Child instrument is carefully examined.

\section{Research Questions}

This study focuses on the IP of Japanese elementary school students who take the Foreign Language Activities class in school. Given the necessity of understanding the underlying structure of IP and the degree to which young learners possess IP, the following research questions were posed:

1. To what extent do the respective configurations of the IP-Child instrument for fifth and sixth graders correspond with the 4-factor configuration of adults?

2. To what extent are the respective configurations of IP of fifth and sixth graders invariant?

3. How much does the level of IP differ between elementary students in the respective grades?

\section{Method}

In this section we begin by explaining the participants and the instrument, the International Posture-Child scale. Thereafter the procedure and analyses will be outlined.

\section{Participants}

Participants in this study were 986 elementary school students from 10 to 12 years of age. Students were enrolled in one of five public elementary schools in the Tokyo area and included 533 fifth graders from 16 classes and 
453 sixth graders from 14 classes. The classes were formed at the beginning of the school year when the students entered fifth grade, meaning the fifth graders had completed just 1 year with their classmates but the sixth graders had spent 2 years together. The participants experienced 35 lessons of Foreign Language Activities per school year (a total of 35 lessons x 45 minutes $=26.25$ hours); thus, the fifth graders had received 1 year of lessons and the sixth graders 2 years of lessons. Those lessons were generally taught by the classroom teacher and an assistant language teacher (ALT) dispatched to the school. ALTs are native or proficient speakers of the target language who are involved in preparing teaching materials for the Foreign Language Activities, which typically focus on exposing students to the target language by using enjoyable activities such as playing games, singing songs, and reading picture books.

\section{Instrument}

To address the need for an age-appropriate instrument, the International Posture Scale for Children (IP-Child, see Appendix) was developed by revising items from the International Posture Scale (Yashima, 2002). Although the scale used in this study included the original 22 items, several revisions were made. First, in consideration of the age of the participants, the original 7-point Likert scale was reduced to four categories (see Borgers, Hox, \& Sikkel, 2004; Monoi-Yamaga, 2010; Pintrich \& Schunk, 1996). Second, the lexis was simplified, with, for example, situations and events in foreign countries changed to either world news or events in foreign countries. Third, the verbs in one of the original items (I often read and watch news about foreign countries) were separated into different items, one of which inquired about watching world news (IFA1) and the second of which (IFA2) asked about reading world news. Finally, two items were added to investigate incidental exposure to news (IFA4) and actions taken to learn about news (IFA5). The IP-Child scale includes the original four factors: Intercultural Friendship Orientation in English Learning (IFOEL; four items), Intercultural ApproachAvoidance Tendency (IAAT; seven items), Interest in International Vocation/ Activities (INTVA; six items), and Interest in Foreign Affairs (IFA; five items).

\section{Protocol}

The IP-Child questionnaire was administered to the participants at the five schools in a paper format once at the end of the school year in March, 2013. The instructions and the questionnaire were given in Japanese. The 
participants were given the option of not participating, but all chose to take part and all completed the questionnaire within 30 minutes.

\section{Analyses}

As stated above, the purpose of this study was to validate the IP-Child scale (Monoi, 2013), an instrument for measuring the IP of Japanese elementary school students. The analyses proceeded as follows. First, the data were screened. Second, exploratory factor analyses (EFAs) using PASW Version 18 (SPSS, 2009) were conducted to ascertain tentative configurations of the IP construct for the two grades in this context. Next, the performance of items and persons as well as the dimensionality of each factor were examined using Winsteps Version 3.70.0 (Lineacre, 2010). Thereafter, the invariance of the second-order IP structure and latent mean differences were examined based on an analysis of means and covariances (MACS; Byrne \& Stewart, 2006; Sörbom, 1974) within the framework of confirmatory factor analysis modeling using EQS 6.1 Build 94 (Bentler, 2007).

The various criteria for the several types of analyses follow. Item fit was judged using the 0.5-1.5 range for MNSQ infit and outfit suggested by Linacre (2006). When assessing dimensionality of the various factors, in a Rasch PCA of residuals, two criteria were assessed: an eigenvalue below 2 and a disattenuated correlation above .70 were considered indicative of multidimensionality. In the structural equation modeling (SEM) analyses, several indices were examined. First, the $\chi^{2}$-to- $d f$ ratio is a useful general guideline for fit evaluation; values near or less than 2 are considered indicative of reasonably good fit (Byrne, 2006). For SRMR, well-fitting models should be less than .08 (Browne \& Cudeck, 1993; Hu \& Bentler, 1999); for CFI, values should ideally be greater than or "close to" .95 for well-fitting models (Hu \& Bentler, 1999). For RMSEA, values of .05 or less indicate models that fit well, and values near .06 (Hu \& Bentler, 1999) or .08 (Brown \& Cudeck, 1993) indicate adequate fit. Finally, in the MACS analysis, from the Lagrange Modifier Test statistics a $\chi^{2}$ value with a probability less than .05 is the criterion for a path that is not invariant (Byrne, 2006).

\section{Results and Discussion}

In this section the results of the factor analyses and the Rasch analyses are detailed, after which the results of the respective analyses are discussed. 


\section{Configuration of the IP-Child Instrument}

First, to address whether the configuration of the elementary school students' IP was the same as that of adults (RQ1), the initial analysis was an EFA of the IP-Child instrument using SPSS. Maximum likelihood extraction with promax rotation was conducted to determine the factor loadings of the 22 items that comprised the four original factors. Before the factor analysis, the assumptions of the analysis were checked and satisfactorily met. The three cases of missing data were replaced by the respective means. No univariate or multivariate outliers were found. Oblique rotation was chosen because the various factors have shown significant degrees of correlation in other studies (Yashima, 2002; Yashima et al., 2004), and it was expected they would correlate strongly in the current study.

For the fifth graders, a single 2-factor configuration emerged that included 17 of the 22 items (five items-all with negative valence-failed to reach the cutoff point of .40; see Stephens, 2002). In this layout, the strongest factor was an amalgam of four IFOEL items, five IAAT items, and three INTVA items, which dealt with one's tendency to approach foreigners either inside or outside Japan; this factor was dubbed simply Approach. Of note is that the factor dealing with approach was labeled Intergroup Approach-Avoidance Tendency in the original instrument, inasmuch as it incorporated both the tendency to approach as well as to avoid foreigners, yet it appears that this new factor configuration addresses only the tendency to approach someone. The second factor consisted of the five IFA items, for which the original label, Interest in Foreign Affairs, was retained.

For the sixth graders, the factor analyses yielded two viable configurations (Table 1). The simpler of the two was identical to the 2 -factor configuration of the fifth graders. However, a 3-factor configuration was also substantively and statistically viable. Although the IFA items remained unchanged, the 12-item International Approach Tendency factor fragmented into a primary factor with only the IAAT items (labeled IAAT) and a second factor consisting of four IFOEL items and two INTVA items (hence labeled IFOEL-INTVA). As shown in Table 1, IFOEL4 loaded on both factors and INTVA4 failed to reach the .40 cutoff criterion in the 3 -factor configuration; however, both items were provisionally retained pending the outcomes of further analyses. Table 1 presents the two configurations for the sixth graders, and the leftmost columns also show the fifth-grade configuration. 
Table 1. Possible Configurations (Pattern Matrices) for the IP-Child Scale for Sixth Graders

\begin{tabular}{|c|c|c|c|c|c|}
\hline \multirow{2}{*}{ Item } & \multicolumn{2}{|c|}{2 -factor ${ }^{\mathrm{a}}$} & \multicolumn{3}{|c|}{ 3-factor } \\
\hline & Approach & IFA & IFOEL-INTVA & IFA & IAAT \\
\hline IFOEL4 & .88 & & .47 & & .49 \\
\hline IAAT1 & .86 & & & & .59 \\
\hline IFOEL1 & .77 & & .58 & & $.23^{\mathrm{b}}$ \\
\hline IAAT3 & .70 & & & & .58 \\
\hline IAAT4 & .68 & & & & .50 \\
\hline IAAT5 & .65 & & & & .75 \\
\hline IFOEL2 & .62 & & .50 & & \\
\hline IFOEL3 & .62 & & .74 & & \\
\hline IAAT7 & .61 & & & & .58 \\
\hline INTVA4 & .58 & & $.29^{\mathrm{b}}$ & & $.25^{b}$ \\
\hline INTVA3 & .53 & $.21^{\mathrm{b}}$ & .73 & & \\
\hline INTVA2 & .46 & & .71 & & \\
\hline IFA2 & & .78 & & .77 & \\
\hline IFA5 & & .69 & $.21^{\mathrm{b}}$ & .62 & \\
\hline IFA1 & & .67 & & .73 & \\
\hline IFA3 & & .58 & & .67 & \\
\hline IFA4 & & .52 & & .58 & \\
\hline Eigenvalue & 6.88 & 2.31 & 6.41 & 1.65 & 1.09 \\
\hline$\%$ of variance & 31.26 & 10.48 & 29.14 & 7.48 & 4.81 \\
\hline Reliability & .86 & .78 & .87 & .81 & .78 \\
\hline
\end{tabular}

Note. Approach = International Approach Tendency; IFA = Interest in Foreign Affairs; IFOEL = Intercultural Friendship Orientation in English Learning; INTVA = Interest in International Vocation/Activities; IAAT = Intergroup Approach-Avoidance Tendency. Factor loadings greater than .20 are shown. The complex factor loadings for Item IFOEL4 are shown in italics.

aThis 2-factor configuration was found to be statistically and substantively valid for both the fifth and the sixth graders. Loadings and factor summary statistics (e.g., eigenvalues) are for the sixth graders.

${ }^{\mathrm{b}}$ Minor loadings greater than .20 and less than the cutoff criterion of 40 . 
The question of whether a 2 -factor or a 3-factor configuration was preferable was considered next. First, interfactor correlations indicated that the two factors correlated moderately $(r=.41)$, although for the 3 -factor configuration two correlation coefficients were slightly lower and one higher (see Table 2). Of note was that IAAT and IFOEL-INTVA, the two factors that resulted when the large Approach factor disintegrated, correlated at $r=.57$, indicating a substantial degree of overlap.

\section{Table 2. Factor Correlation Matrices for 2-Factor and 3-Factor Configurations for Sixth Graders}

\begin{tabular}{lccc}
\hline \multicolumn{1}{c}{ Factor } & 1 & 2 & 3 \\
\hline 1. IAAT (Approach) & - & .41 & \\
2. IFA & .31 & - & \\
3. IFOEL-INTVA & .57 & .40 & - \\
\hline
\end{tabular}

Note. IAAT = Intergroup Approach-Avoidance Tendency; IFA = Interest in Foreign Affairs; IFA $=$ Interest in Foreign Affairs; INTVA $=$ Interest in International Vocation/Activities. The upper right-hand correlation is from the 2-factor configuration, whereas the correlations for the 3-factor correlation are shown in the lower lefthand triangle.

Further evidence of the statistical viability of the respective factors emerged from Rasch analyses (Table 3). Fit statistics indicated that nearly all items performed satisfactorily in the respective configurations; one item in the fifth-grade Approach factor (Item IAAT7) produced a slightly excessive infit value of 1.51, yet given the miniscule level of misfit, the item was retained in subsequent analyses. The various reliability values were adequate, and most of the separation values were also sufficient. The values for the 3 -factor IAAT factor were somewhat low (i.e., substantially below 2); the addition of more items would likely address this shortcoming. 
Table 3. Rasch Statistics for Various Configurations

\begin{tabular}{|c|c|c|c|c|c|c|c|}
\hline & \multicolumn{3}{|c|}{ Reliability } & \multicolumn{2}{|c|}{ Separation } & \multicolumn{2}{|c|}{ Fit statistic ranges } \\
\hline & $k$ & Per & Item & Per & Item & Infit & Outfit \\
\hline \multicolumn{8}{|c|}{ Fifth-grade 2-factor configuration } \\
\hline Approach & 12 & .86 & .99 & 2.72 & 9.78 & $.79-1.51$ & $.74-1.4 \mathrm{C}$ \\
\hline IFA & 5 & .77 & 1.00 & 1.84 & 14.40 & $.84-1.19$ & $.84-1.17$ \\
\hline \multicolumn{8}{|c|}{ Sixth-grade 2-factor configuration } \\
\hline Approach & 12 & .86 & .99 & 2.48 & 8.39 & $.74-1.48$ & $.70-1.42$ \\
\hline IFA & 5 & .79 & .99 & 1.96 & 13.96 & $.93-1.16$ & $.95-1.11$ \\
\hline \multicolumn{8}{|c|}{ Sixth-grade 3-factor configuration } \\
\hline IFOEL-IN & $6^{a}$ & .80 & .99 & 2.03 & 8.13 & $.76-1.37$ & $.76-1.33$ \\
\hline IFA & 5 & .79 & .99 & 1.96 & 13.96 & $.93-1.16$ & $.95-1.11$ \\
\hline IAAT & $6^{a}$ & .72 & .97 & 1.60 & 6.24 & $.74-1.21$ & $.74-1.20$ \\
\hline
\end{tabular}

Note Approach = International Approach Tendency; IFA = Interest in Foreign Affairs; IFOEL = Intercultural Friendship Orientation in English Learning; INTVA = Interest in International Vocation/Activities; IAAT = Intergroup Approach-Avoidance Ten-

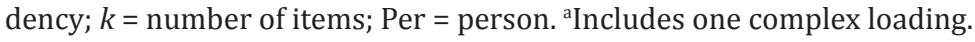

The dimensionality of each factor was examined with a Rasch principal component analysis (PCA), which indicated that the IFA factor was strongly unidimensional for both the fifth and sixth graders (see Table 4). The dimensionality of the large Approach factor initially appeared somewhat suspect with eigenvalues of 2.0 and 2.2, respectively, but the disattenuated correlation values of .94 and .97 were indicative of satisfactorily unidimensional factors. Ultimately, for all of the factors in the configurations, the respective Rasch PCAs of residuals indicated sufficient unidimensionality. 
Table 4. Rasch Dimensionality Statistics for Various Configurations

\begin{tabular}{lcccccc}
\hline & \multicolumn{3}{c}{ Variance expl } & & \multicolumn{3}{c}{ PCA of residuals } \\
\cline { 2 - 3 } \cline { 7 - 7 } Item & Eigen & \% var & & Eigen & $\%$ var & D-Corr \\
\hline Fifth-grade 2-factor configuration & & & & & \\
Approach & 13.8 & 53.4 & & 2.0 & 7.6 & .94 \\
IFA & 7.2 & 59.1 & & 1.5 & 12.6 & $>.99$ \\
\hline Sixth-grade 2-factor configuration & & & & \\
Approach & 11.7 & 49.4 & & 2.2 & 9.4 & .97 \\
IFA & 7.9 & 61.2 & & 1.6 & 12.2 & $>.99$ \\
\hline Sixth-grade 3-factor configuration & & & & \\
IFOEL-INTVA & 6.4 & 56.0 & & 1.6 & 14.3 & $>.99$ \\
IFA & 7.9 & 61.2 & & 1.6 & 12.2 & $>.99$ \\
IAAT & 5.4 & 52.1 & & 1.6 & 15.2 & .91 \\
\hline
\end{tabular}

Note. Variance expl = variance explained by the measures. Approach $=$ International Approach Tendency; IFA = Interest in Foreign Affairs; IFOEL = Intercultural Friendship Orientation in English Learning; INTVA = Interest in International Vocation/ Activities; IAAT = Intergroup Approach-Avoidance Tendency. Eigen = eigenvalue; \% var $=\%$ of unexplained variance; $\mathrm{D}$-Corr $=$ disattenuated correlation.

The overall result was that all factors in both configurations were statistically viable. Moreover, both the 2-factor and the 3-factor configurations for the sixth graders were shown to be robust, which exemplifies the adage that multiple models may adequately account for the data. With two viable and valid models from which to choose, in this study we opted for the 2-factor model to allow comparison between the two grades.

To this point we have found preliminary support for configurations of the International Posture construct for the two grades. To further investigate IP, we will use the 2-factor configuration for both grades and investigate (a) whether the instrument is invariant across the two groups (RQ2), and, if so, (b) whether the differences in the latent means of the respective factors are statistically significant (RQ3). These two issues will be addressed in the following sections using SEM. 


\section{Establishment of Baseline Models for Fifth-Grade and Sixth-Grade Students}

First, the configurations for the respective grades were examined with CFA models constructed to represent the data. The original 4-factor configuration was tested first, after which the simplest possible model, a 1-factor configuration, was scrutinized. Next, the respective baseline models for the two grades were tested, meaning the 2-factor structure for the fifth graders and both the 2-factor and 3-factor configurations for the sixth graders.

The 2-factor configuration based on the first EFA is shown in Figure 1. This configuration includes 17 measured variables (the questionnaire items), two 1st-order factors, one 2nd-order factor, two disturbance terms associated with the 1st-order factors, and 17 error terms (for the sake of clarity, the disturbances and error terms are not shown). The upper factor, Approach, includes 12 items, of which IFOEL4 and INTVA4 (denoted with daggers) have only provisional status. For both the fifth graders and the sixth graders, data exhibited elevated levels of kurtosis, so results were based on robust statistics.

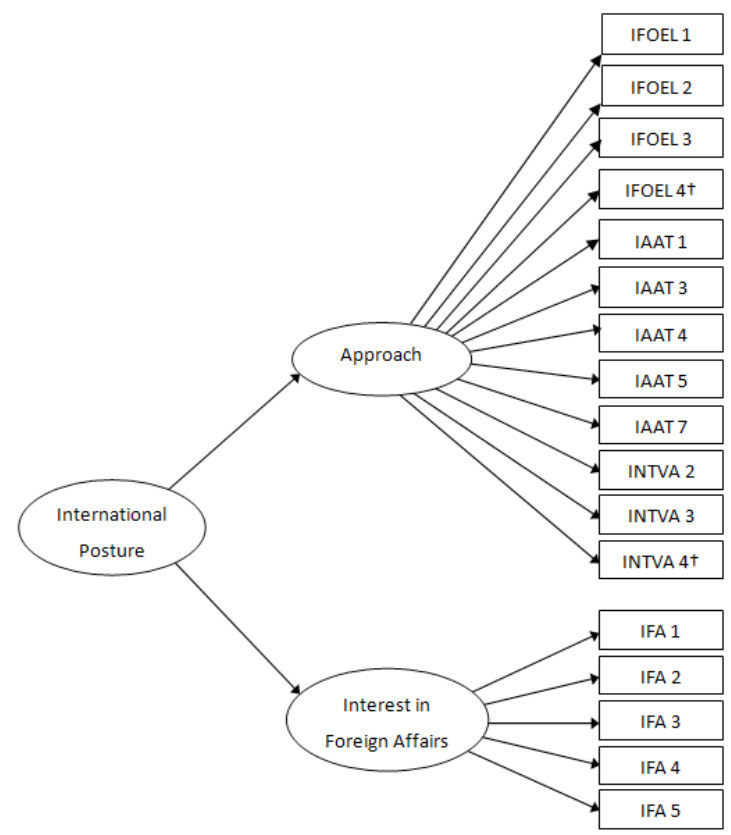

Figure 1. Revised configuration of International Posture-Children for fifth graders. The two items denoted with daggers have provisional status. 
For the other configurations, the original 4-factor configuration for International Posture (denoted 4-factor-Y) exhibited poor fit for both the fifth graders and the sixth graders (see Table 3 ). These results underscore the importance of checking the use of instruments in contexts outside those for which they were originally intended. In the following rows, the respective 1 -factor configurations exhibited even poorer fit, a finding that indicated that International Posture was, as expected, not a unidimensional construct.

For the fifth graders, successive queries indicated that respecification with two error covariances resulted in a well-fitting model (denoted 2-factor, $2 e$ ) with $\mathrm{SB} \chi^{2}(116)=288.97 ;{ }^{*} \mathrm{CFI}=.938 ;{ }^{*} \mathrm{RMSEA}=.053$, with $90 \%$ C.I. $=.045$ to .061 . (See Table 5; the asterisks indicate that CFI and RMSEA are based on robust statistics in light of the elevated level of kurtosis.) The two provisional items, IFOEL4 and INTVA, both returned statistically significant path coefficients and were thus retained in the model.

For the sixth graders, four substantive error covariances were added to yield a model (2-factor, $4 e$ ) with fit statistics that were incrementally worse yet still adequate: $\mathrm{SB} \chi^{2}(114)=278.42 ;{ }^{*} \mathrm{CFI}=.931 ;{ }^{*} \mathrm{RMSEA}=.057$, with $90 \%$ C.I. $=.048$ to .065 . All parameter estimates were viable and statistically significant, including those of the two provisional items. As noted, for the fifth graders the 2-factor model yielded acceptable fit, and for the sixth graders the fit statistics for the 2-factor model were quite similar and thus also considered adequate.

\section{Table 5. Comparison of Various Configurations for Fifth-Grade and Sixth-Grade Students}

\begin{tabular}{|c|c|c|c|c|c|c|c|}
\hline Factor & $\mathrm{SB} \chi^{2}$ & $d f$ & $\chi^{2} / d f$ & ${ }^{*} \mathrm{CFI}$ & *NNFI & *RMSEA & 90\% C.I. \\
\hline \multicolumn{8}{|c|}{ Fifth graders $(n=533)$} \\
\hline 4-factor-Y & 572.33 & 206 & 2.78 & .880 & .826 & .058 & {$[.052, .064]$} \\
\hline 1-factor & & 152 & 4.74 & & & & \\
\hline 2 -factor, $2 \mathrm{e}^{\mathrm{a}}$ & 288.97 & 116 & 2.49 & .938 & .928 & .053 & 061] \\
\hline \multicolumn{8}{|c|}{ Sixth graders $(n=453)$} \\
\hline 4-factor-Y & & 205 & & & & & \\
\hline 1-factor & 84.48 & 209 & 4.71 & .713 & .683 & .091 & {$[.085, .096]$} \\
\hline 2 -factor, $4 \mathrm{e}^{\mathrm{a}}$ & 278.42 & 114 & 2.61 & .931 & .918 & .057 & {$[.048, .065]$} \\
\hline 3-factor, $3 \mathrm{e}^{\mathrm{a}}$ & 330.80 & 130 & 2.54 & .919 & .905 & .059 & {$[.051, .067]$} \\
\hline
\end{tabular}

Note. Y denotes the original configuration of International Posture from Yashima (2002). Because of the elevated level of kurtosis for both grades, robust statistics 
(denoted with an asterisk) were used. NNFI is the Bentler-Bonett (Tucker-Lewis) nonnormed fit index.

${ }^{a}$ The $2 \mathrm{e}, 4 \mathrm{e}$, and $3 \mathrm{e}$ notations indicated the number of error covariances added as post hoc model specifications; thus, two, four, and three error covariances were added to the respective models.

Of interest was that the 3 -factor configuration for the sixth graders also exhibited satisfactory fit that, although incrementally worse, was quite similar to the fit of the 2 -factor configuration. In particular, the values of CFI, NNFI, and RMSEA were slightly better for the 2 -factor model although the $\chi^{2} / d f$ ratio was better (i.e., lower) for the 3 -factor model. This offers some support for a gradual change in the IP construct from a bidimensional construct for fifth graders into a more complex trifurcate construct as the children age.

Thus, the results to this point corroborate the earlier finding above that both a 2-factor model and a 3-factor model are viable for the sixth graders.

\section{Testing for Invariance Across Grades}

The next step was to test for invariance across the two independent samples (i.e., the two grades). Testing for invariance is accomplished through a series of hierarchical steps, the first of which is an examination of the baseline ("configural") models for the respective groups that were established in the previous section. Thereafter the equivalence of parameters is tested at increasingly stringent levels, and a finding of invariance (either partial or total) suggests that the model is operating equivalently across the two groups and that the means of latent variables can subsequently be compared.

\section{Configural Invariance}

Having established the respective configurations of the two baseline models in the previous section, the next step was to examine configural invariance using SEM. In this step the number of factors and the array of factor loadings must be identical across groups. As such, no equality constraints are imposed as the two baseline models are tested simultaneously. The fit of this multigroup configural model (Line 1 in Table 6) provides the fit statistics against which subsequent, more tightly-constrained models were compared. The test for configural invariance yielded good fit of the overall model to the data with $\mathrm{SB}^{2}(200)=500.80 ;{ }^{*} \mathrm{CFI}=.939$; $\mathrm{SRMR}=.039,{ }^{*} \mathrm{RM}-$ $\mathrm{SEA}=.055$, with $90 \%$ C.I. $=.049$ to .061 (Table 6; the asterisks again indicate the use of robust statistics). These values suggest that the overall model is configurally invariant. 


\section{Table 6. Tests for Invariance of International Posture-Child Hierarchal Structure: Goodness-of-Fit Statistics}

\begin{tabular}{lccccccc}
\hline Model & $\mathrm{SB} \chi^{2}$ & $d f$ & ${ }^{*} \mathrm{CFI}$ & SRMR & ${ }^{*}$ RMSEA & $90 \%$ C.I. & $\Delta^{*}$ CFI \\
\hline $\begin{array}{l}\text { 1. Configural } \\
\text { 2. 1st-order }\end{array}$ & 500.80 & 200 & .939 & .050 & .055 & {$[.049, .061]$} & \\
$\begin{array}{l}\text { 3. } 1 \text { st- \& 2nd- } \\
\text { order }\end{array}$ & 526.39 & 216 & .937 & .061 & .054 & {$[.048, .060]$} & .002 \\
$\begin{array}{l}\text { 4. Intercepts- } \\
\text { obs }\end{array}$ & 534.66 & 226 & .936 & .054 & .055 & {$[.049, .061]$} & .003 \\
$\begin{array}{l}\text { 5. Intercepts- } \\
\text { latent }\end{array}$ & 536.99 & 226 & .936 & .061 & .055 & {$[.049, .061]$} & .003 \\
$\begin{array}{l}\text { 6. 1st-order } \\
\text { means }\end{array}$ & 513.28 & 212 & .939 & .055 & .054 & {$[.048, .060]$} & .000 \\
\hline
\end{tabular}

Note. Because of the elevated level of kurtosis for both grades, robust statistics (denoted with asterisks) were used. 1st-order = First-order factor loadings; 1 st- \& 2nd order $=$ First $\&$ second order factor loadings; Obs = observed. The $\Delta^{*} C F I$ value represent differences between the configural model (\#1) and the respective model; thus, $\Delta^{*} \mathrm{CFI}$ for Model 6 yielded $.000(=.939-.939)$.

\section{Factor Loading Invariance}

After configural invariance has been established, the subsequent SEM steps involve increasingly stringent levels of constraints as more parameters are fixed in subsequent steps. The first level consists of factor loading constraints on all first-order factor loadings (i.e., on the items comprising IFA and Approach, respectively). As shown in Line 2 of Table 6, the fit statistics indicated a well-fitting model for which the change in ${ }^{*} \mathrm{CFI}$ was just $.003(=.939-.936)$; a change in ${ }^{*} \mathrm{CFI}$ of less than .01 indicates that the two models can be considered invariant (Cheung \& Rensvold, 2002). The Lagrange Modifier Test statistics from this iteration yielded one incremental $\chi^{2}$ value with a probability less than .05 , indicating that IAAT3 (I would talk to an international student if there were one at school) was differentially valid across the two grades. Although the item itself offered no hint of why that was the case, the context did: In three of the schools included in this study, one fifth-grade student was not Japanese. Thus, for 203 of the 204 fifth graders in that school (38\% of the total number of 533 fifth-grade participants), talking to an international student was a very plausible scenario, not just an abstraction. For the sixth graders, however, the school environment in- 
cluded only Japanese students, so interacting with an international student was likely not among their classroom experiences. In subsequent analyses this factor loading was released, thus allowing it to be freely estimated; the other loadings remained fixed.

With partial invariance established for the first-order factor loadings, the next step is to constrain the single second-order loading in addition to the first-order factor loadings. When this was done, results indicated a wellfitting model with only a minimal change in ${ }^{*}$ CFI of .002 (=.939 - .937). The second-order factor loading was thus considered to be invariant across the two grades.

Although the invariance of error covariances can be tested, this step is generally considered unnecessarily stringent (Widaman \& Reise, 1997). Thus, with just one common error covariance in the model, this step was not conducted.

\section{Intercept Invariance}

Given the invariance of the first-order and second-order factor loadings, the subsequent step is to constrain intercept loadings in addition to the factor loadings constrained in the previous steps. The intercepts to be tested include observed intercepts and then latent factor intercepts. When the observed intercepts were constrained (Model 4 in Table 6), results again indicated a well-fitting model with a change in ${ }^{*} \mathrm{CFI}$ of .003, indicating that the observed intercepts were invariant across the two groups. In the second step, the latent factor loadings were constrained (Model 5). Results again indicated a well-fitting model for which the ${ }^{*} \mathrm{CFI}$ value was again minimal (.003). Thus, the intercepts for both observed variables and latent variables were considered to be invariant.

Testing for invariance of the measurement component of the hypothesized model represents a necessary prerequisite to the testing of latent mean differences across the two groups. The tests conducted to this point were quite rigorous yet yielded satisfactory results at each of the five steps. We therefore conclude that with one exception (Item IAAT3), the items constituting the IP-Child instrument were operating equivalently across the two groups.

\section{Latent Mean Differences}

With a preponderance of evidence supporting the invariance of both factor loadings and intercepts, the final step is to check for group differences in latent factor means, first for the first-order loadings (i.e., the two factors) 
and then for the single second-order loading (i.e., the overall IP factor). To do so involves placing equality constraints on the first-order and higher order factor loadings as well as on the intercepts of both the observed variables and the latent mean factors. Thereafter, the means for one group are fixed to zero to provide a reference point (Bentler, 2006; Byrne, 2006), and finally the statistical significance of the differences between the latent means for each factor for the two groups is assessed using the $z$ statistic.

Shown as Model 6 in Table 6, the results of the 1st-order latent mean differences indicated a nicely fitting model. However, the differences in latent means for Approach and IFA both failed to reach statistical significance with $z=-.08$ and $z=.25$, respectively, which fall well below the 1.96 threshold that would indicate a statistically significant difference at the $p<.05$ level. Thus, we conclude that the fifth and the sixth graders exhibited no statistically discernible difference on either of the respective factors. The means of the two groups are shown in Table 7, as are the $z$ scores for the respective factors.

The final step would be to examine the difference in the means of the second-order factor (IP), but because the two 1st-order factor means exhibited no significant differences, this step was not undertaken.

\section{Table 7. Comparison of the Fifth- and Sixth-Grade Means of International Posture}

\begin{tabular}{lccrrr}
\hline & \multicolumn{2}{c}{ Approach } & & \multicolumn{2}{c}{ IFA } \\
\cline { 2 - 3 } \cline { 5 - 6 } & $M$ & $S D$ & & $M$ & $S D$ \\
\hline fifth graders & 2.91 & .60 & & 2.51 & .70 \\
sixth graders & 2.89 & .55 & & 2.47 & .68 \\
$\Delta_{\text {mean }}$ & -.02 & .05 & & -.04 & .01 \\
\cline { 2 - 3 } \cline { 5 - 6 }$Z_{\text {latent mean }}$ & \multicolumn{2}{r}{-.08} & & \multicolumn{2}{c}{.25} \\
\hline
\end{tabular}

Note. Approach = International Approach Tendency; IFA = Interest in Foreign Affairs. $z_{\text {latent mean }}$ is the value indicating the presence or lack of statistical significance of the 1st-order latent factor means.

This series of tests of increasingly tightly constrained models offers persuasive evidence that the respective models exhibit partial measurement invariance, which allows for comparison of the factor means of the two models. Those means were found to be statistically indistinguishable. 


\section{Discussion}

For the present study, three research questions were posed. Regarding the first (To what extent do the respective configurations of the IP-Child instrument for fifth and sixth graders correspond with the 4-factor configuration of adults?), the IP construct for upper elementary school students differed from that of university students and adults. In particular, the configurations of the respective groups were less complex, with fifth graders possessing a 2 -factor structure that consisted of Interest in Foreign Affairs and International Approach Tendency and sixth graders having either an identical 2-factor structure or a more complex 3-factor structure that included Interest in Foreign Affairs, Approach, and the composite IFOEL-INTVA factor. Although the structure differed somewhat between the groups, who had had different lengths of exposure to a foreign language, both configurations diverged from that of adults.

As noted, the second query (To what extent are the respective configurations of International Posture of fifth and sixth graders invariant?) returned somewhat surprising results in which two configurations were valid for the sixth graders. The simpler, 2 -factor structure matched that of the fifth graders, whereas in the 3-factor model the Approach factor split into two factors, Approach and IFOEL-INTVA. Although the 2-factor layout returned slightly better fit statistics, both configurations were statistically and substantively robust, suggesting that the IP construct was in the process of evolving.

Third, the use of the simpler 2-factor configuration for the sixth graders allowed for direct comparison of the two groups. Results concerning the third research question (How much does the level of IP differ between elementary students in the respective grades?) were unexpected: The levels of the respective Approach and IFA factors for IP for the fifth and sixth graders were found to be statistically indistinguishable. This result might be attributable to the relatively limited time devoted to English. As noted, the Foreign Language Activities consisted of 35 lessons over the course of one academic year, which equates to about one lesson per week. Simply put, the effect of such limited exposure to a foreign language and cultural information about other countries might have been insufficient to facilitate an increase in IP. Other skills (e.g., math and Japanese) are allotted far more time over many years, and thus to anticipate a substantial change in IP over a short interval and with a somewhat limited amount of instruction and exposure may be unreasonable.

Other reasons might be worthy of consideration, too. One might be a decline in novelty as the Foreign Language Activities shift from a new and ex- 
citing endeavor to one that is just another school subject. In the remainder of the elementary school curriculum, students receive instruction in social studies, in the course of which some information is presented about Japan's relationships with other countries. Although this exposure certainly adds to students' knowledge, the focus is naturally Japan, and the duration is limited to just the latter half of the sixth grade.

Of course, this result indicates that although the IP-Child instrument can be used, it should be used with care. The structure of the IP-Child instrument, although found to differ in these contexts from configurations found in previous research on adults, remains a multidimensional construct that should be validated for any context in which it is used.

\section{Conclusion}

In this study the focus was on validating an instrument for measuring elementary school students' International Posture and examining the level of IP for the two groups, one of which had experienced an additional year of Foreign Language Activities. The results indicated that these young learners did not show a discernible difference in the level of IP, which at face value might disappoint those whose underlying aim is to help young learners develop a positive attitude toward communication in a foreign language. However, the development of IP in young students may well require more time than just 1 or 2 years - children often require a substantial period of time to develop skills or propensities. A logical step might be starting what MEXT calls Foreign Language Activities even earlier, as is done in other L2 contexts.

This study highlighted several areas in need of further investigation. Different samples from other schools or regions would allow for replication. A further sequel could be to examine and track IP in junior high school students, for whom the structure of IP might be further removed from that of elementary students in the upper two grades of elementary school and closer to configurations found for adult learners.

An ancillary issue for future research is the performance of the five negatively worded items, all of which failed to load satisfactorily in the factor analysis. This is not entirely surprising inasmuch as questionnaire items with negative valence have been found to be problematic for adult learners (e.g., Barnette, 2000; Roszkowski \& Soven, 2010) as well as young learners (Benson \& Hocevar, 1985; Corwyn, 2000; Monoi, 2014). Thus, addressing this issue in detail would be wise. 
Finally, further research on IP in young L2 learners needs to proceed with due caution paid to instrument validation. As shown in the current study, the targeted construct might well differ for informants of similar yet not identical ages. If such vigilance is forthcoming, future studies will likely shed further insight on the ongoing efforts of MEXT and classroom practitioners to instill a positive attitude toward foreign languages in young learners.

\section{Note}

1. Foreign Language Activities are regular periods for elementary school students to have access to a foreign language (which does not necessarily have to be English). However, in Section III, Teaching plans and notes on the contents in the Course of Study, MEXT (2008) clarified, "Foreign Language Activities should be conducted, in principle, in English" (p. 1). Therefore, in this paper Foreign Language Activities should be understood to be English education.

James A. Elwood, EdD, is an associate professor at Meiji University in Japan. His research interests include psychometrics, technology in second language acquisition, and uses of puppetry in education.

Naoko Monoi, EdD, has taught English at the elementary school and the university levels in Japan. She is an associate professor at Chiba University in Japan. Her research interests include elementary school students' affective development in motivation and interests in English learning and second language acquisition.

\section{References}

Barnette, J. J. (2000). Effects of stem and Likert response option reversals on survey internal consistency: If you feel the need, there is a better alternative to using those negatively worded items. Educational and Psychological Measurement, 60, 361-370. http://dx.doi.org/10.1177/00131640021970592

Benesse Educational Research and Development Center. (2007a). Dai ikkai shougakkou eigo ni kansuru kihon chousa (hogosha chousa) houkokusho [A basic survey regarding elementary school English (a survey of parents): No.1]. Tokyo: Author.

Benesse Educational Research and Development Center. (2007b). Dai ikkai shougakkou eigo ni kansuru kihon chousa (kyouin chousa) houkokusho [A basic survey regarding elementary school English (a survey of teachers): No.1]. Tokyo: Author. 
Benson, J., \& Hocevar, D. (1985). The impact of item phrasing on the validity of attitude scales for elementary school children. Journal of Educational Measurement, 22, 231-240.

Bentler, P. M. (2007). EQS 6.1, Build 94 [Computer software]. Encino, CA: Multivariate Software.

Block, J., \& Robins, R. W. (1993). A longitudinal study of consistency and change in self-esteem from early adolescence to early adulthood. Child Development, 64, 909-923. http://dx.doi.org/10.1111/j.1467-8624.1993.tb02951.x

Borgers, N., Hox, J., \& Sikkel, D. (2004). Response effects in surveys on children and adolescents: The effect of number of response options, negative wording, and neutral mid-point. Quality \& Quantity, 38, 17-33. http://dx.doi.org/10.1023/B:QUQU.0000013236.29205.a6

Browne, M. W., \& Cudeck, R. (1993). Alternative ways of assessing model fit. In K. A. Bollen \& J. S. Long (Eds.), Testing structural equation models (pp. 136-159). Thousand Oaks, CA: Sage.

Byrne, B. M. (2006). Structural equation modeling with EQS: Basic concepts, applications, and programming (2nd ed.). Mahwah, NJ: Erlbaum.

Byrne, B. M., \& Stewart, S. M. (2006). Teacher's corner: The MACS approach to testing for multigroup invariance of a second-order structure: A walk through the process. Structural Equation Modeling, 13, 287-321. http://dx.doi.org/10.1207/s15328007sem1302_7

Cheung, G. W., \& Rensvold, R. B. (2002). Evaluating goodness-of-fit indexes for testing measurement invariance. Structural Equation Modeling, 9, 233-255. http://dx.doi.org/10.1207/S15328007SEM0902_5

Corwyn, R. F. (2000). The factor structure of global self-esteem among adolescents and adults. Journal of Research in Personality, 34, 357-379. http://dx.doi. org/10.1006/jrpe.2000.2291

Elwood, J. A. (2011). Enriching models of willingness to communicate: The role of extroversion, ego permeability, and distancing (Unpublished doctoral dissertation). Temple University, Tokyo.

Errington, J. (2009). Motivation, international posture and Chinese core cultural values: Toward a theory of motivation in Chinese ESL (Unpublished master's thesis). University of London, London.

Gardner, R. C. (1985). Social psychology and second language learning: The role of attitudes and motivation. London: Edward Arnold.

Harter, S. (1982). The perceived competence scale for children. Child Development, $53,87-97$. 
Hu, L-T., \& Bentler, P. M. (1999). Cutoff criteria for fit indexes in covariance structure analysis: Conventional criteria versus new alternatives. Structural Equation Modeling, 6, 1-55. http://dx.doi.org/10.1080/10705519909540118

Kunimoto, K. (2005). Shougakkou 4 nensei no eigo gakushuusha no shinri youin ni kansuru kenkyuu [A study on the psychological factors of primary school fourth-grade learners of English]. JASTEC, 24, 41-56.

Kunimoto, K. (2006). Eigo e no koukando ga shougaku 4, 5 nensei no eigo gakushuu douki zuke ni oyobosu eikyou [Effects of interest in English on motivation to learn English of fourth and fifth graders]. JASTEC, 25, 75-88.

Linacre, J. M. (2006). A user's guide to WINSTEPS. Chicago, IL: Winsteps.com

Linacre, J. M. (2010). Winsteps® (Version 3.70.0) [Computer software]. Beaverton, OR: Winsteps.com

MacIntyre, P. D., \& Charos, C. (1996). Personality, attitudes, and affect as predictors of second language communication. Journal of Language and Social Psychology, 15, 3-26. http://dx.doi.org/10.1177/0261927X960151001

Marsh, H. W., Barnes, J., Cairns, L., \& Tidman, M. (1984). Self-description questionnaire: Age and sex effects in the structure and level of self-concept for preadolescent children. Journal of Educational Psychology, 76, 940-956. http://dx.doi.org/10.1037/0022-0663.76.5.940

Matsumiya, N. (2005). Jidou ga fuan wo kanjiru eigo katsudou bamen to sono youin no mosaku [A study on anxiety felt by pupils during English activities at elementary schools]. JASTEC, 24, 57-70.

Matsumiya, N. (2006). Jidou ga konomu katsudou ni kansuru ishiki chousa: Fuan no tsuyosa ni shouten wo atete [A survey on the activities liked and disliked by elementary school students: With special reference to their degree of anxiety felt during the English lesson]. JASTEC, 25, 89-106.

The Ministry of Education, Culture, Sports, Science and Technology [MEXT]. (2008). Shougakkou gakushuu shidou youryou [The curriculum guideline for elementary school]. Tokyo: Author.

The Ministry of Education, Culture, Sports, Science and Technology [MEXT]. (2012). Shougakkou gaikokugo katsudou jisshi shidou joukyou chousa [The report of the survey of the implementation of Foreign Language Activities at elementary school]. Tokyo: Author.

Monoi, N. (2013). Shougakkou gaikokugo katsudou ni miru jidou no kokusai-teki shikousei [Effects of Foreign Language Activities on pupils' international posture]. JASTEC Journal, 32, 19-35. 
Monoi, N. (2014). Shitsumonshi ni okeru koutei, hitei no koumoku hyougen ga jidou no kaitou ni motarasu eikyou [Effects of positive and negative wording in questionnaire items on children's responses to the questionnaire]. JASTEC Journal, 33, 23-37.

Monoi-Yamaga, N. (2010). English activities in international understanding lessons in Japanese public elementary school (Unpublished doctoral dissertation). Temple University, Tokyo.

Nakazawa, J., \& Ino, S. (1984). Doubutsu gainen no hattatsu-teki kentou: Cluster bunseki to suuryou-ka IV rui ni yoru [Analysis of development of the concept of animals by cluster analysis and quantification method IV]. Bulletin of the Faculty of Education, Chiba University. Part I, 181-196.

Nishida, R. (2011). Elementary school pupils' motivation and affective variables in foreign language activities as related to annual hours of English instruction. LET Kansai Chapter, 15, 1-15.

Nishida, R. (2012). A longitudinal study of motivation, interest, CANDO and willingness to communicate in foreign language activities among Japanese fifth-grade students. Language Education and Technology, 49, 23-45.

Nishida, R., \& Yashima, T. (2009). An investigation of factors affecting willingness to communicate and interest in foreign countries among young learners. Language Education \& Technology, 46, 151-170.

Pintrich, P. R., \& Schunk, D. H. (1996). Motivation in education: Theory, research, and applications. Englewood, NJ: Prentice-Hall.

Roszkowski, M. J., \& Soven, M. (2010). Shifting gears: Consequences of including two negatively worded items in the middle of a positively worded questionnaire. Assessment \& Evaluation in Higher Education, 35, 117-134. http://dx.doi.org/10.1080/02602930802618344

Sörbom, D. (1974). A general method for studying differences in factor means and factor structure between groups. British Journal of Mathematical and Statistical Psychology, 27, 229-239. http://dx.doi.org/10.1111/j.2044-8317.1974.tb00543.x

Statistical Package for the Social Sciences [SPSS]. (2009). PASW Statistics for Windows, Version 18.0 [Computer software]. Chicago: Author.

Stephens, J. P. (2002). Applied multivariate statistics for the social sciences (4th ed.). Hillsdale, NJ: Erlbaum.

Tracey, T. J. G. (2002). Development of interests and competency beliefs: A 1-year longitudinal study of fifth- to eighth-grade students using the ICA-R and structural equation modeling. Journal of Counseling Psychology, 49, 148-163. http://dx.doi.org/10.1037/0022-0167.49.2.148. 
Widaman, K. F., \& Reise, S. P. (1997). Exploring the measurement invariance of psychological instruments: Applications in the substance use domain. In K. J. Bryant, M. Windle, \& S. G. West (Eds.), The science of prevention (pp. 281-324). Washington, DC: American Psychological Association.

Yamaga, N. (2007). Children's affective changes in English activities: A trial to invent a measurement of children's affects. In K. Bradford-Watts (Ed.), JALT2006 Conference Proceedings (pp. 192-208). Tokyo: JALT.

Yashima, T. (2000). Orientations and motivation in foreign language learning: A study of Japanese college students. JACET Bulletin, 31, 121-133.

Yashima, T. (2002). Willingness to communicate in a second language: The Japanese EFL content. The Modern Language Journal, 86, 54-66. http://dx.doi.org/10.1111/1540-4781.00136

Yashima, T., \& Zenuk-Nishide, L. (2008). The impact of learning contexts on proficiency, attitudes, and L2 communication: Creating an imagined international community. System, 36, 566-585.

http://dx.doi.org/10.1016/j.system.2008.03.006

Yashima, T., Zenuk-Nishide, L., \& Shimizu, K. (2004). The influence of attitudes and affect on willingness to communicate and second language communication. Language Learning, 54, 119-152.

http://dx.doi.org/10.1111/j.1467-9922.2004.00250.x

\section{Appendix}

\section{The International Posture Scale for Children (IP-Child)}

(Japanese version)

Intercultural Friendship Orientation in English Learning

IFOEL 1. 英語を勉強して、世界のいろいろな国の人たちと会って話をしてみ たいです。

IFOEL 2. 英語を勉強して、世界のいろいろな国の人たちやその人たちのくら しについて知りたいです。

IFOEL 3．英語を勉強して、世界のいろいろな国の人たちと一緒に仕事がして みたいです。

IFOEL 4. 英語を勉強して、世界のいろいろな国の人たちと友だちになりたい です。

Intergroup Approach-Avoidance Tendency

IAAT 1. 外国の人たちと友だちになりたいです。 
IAAT 2.もし、町で外国の人たちと出会っても、なるべく話さないようにする と思います。(R)

IAAT 3. 学校に外国からきた友だちがいたら、話しかけようとします。

AAT 4. もし、自分に外国の友だちができて、しばらく自分の家に泊まること になったらいいと思います。

IAAT 5. もし、近くに外国の人たちがすんでいたら、親切にしたいと思います。

IAAT 6. もし、となりの家に外国の人がひつこしてきたら、なんとなく不安な 気持ちになると思います。(R)

IAAT 7. レストランや駅で、日本語のできない外国の人たちがこまっていた ら、助けてあげたいと思います。

Interest in International Vocation/Activities

INTVA 1. 自分の町にずっと住みたいです。(R)

INTVA 2. 日本だけではなく、いろいろな国に住んでみたいです。

INTVA 3.外国の人たちがたくさんいるところで、はたらいてみたいです。

INTVA 4. 外国で、困っている人たちを助けるためにはたらいてみたいです。

INTVA 5. 外国のできごとは自分の生活とあまり関係がないと思います。(R)

INTVA 6. 大きくなって、外国にでかけることの多い仕事をするのはさけたい と思います。(R)

Interest in Foreign Affairs

IFA 1.」くくレビやインターネットで海外のニュースを見ます。

IFA 2.」く新聞や本で海外のできごとを読みます。

IFA 3.よく家族や友だちと海外のできことについて話します。

IFA 4.」よく海外のニュースやできごとを耳にします。

IFA 5. よく海外のニュースやできごとをしらべます。

(English version)

Intercultural Friendship Orientation in English Learning

IFOEL 1. I study English because it will allow me to meet and talk with foreigners.

IFOEL 2. I study English because it will allow me to get to know various cultures and peoples.

IFOEL 3. I study English because I'd like to work with foreigners.

IFOEL 4. I study English because I'd like to have friends who are foreigners. 
Intergroup Approach-Avoidance Tendency

IAAT 1. I want to make friends with foreigners.

IAAT 2. I try to avoid talking with foreigners if I can. (R)

IAAT 3. I would talk to an international student if there were one at school.

IAAT 4. I would be happy if a friend from abroad stayed in my house for a couple of nights.

IAAT 5. I want to be kind to foreigners living in my neighborhood.

IAAT 6. I would feel somewhat uncomfortable if a foreigner moved in next door. (R)

IAAT 7. I would help a foreigner having trouble communicating in Japanese at a restaurant or station.

Interest in International Vocation/Activities

INTVA 1. I want to live in my hometown when I grow up. (R)

INTVA 2. I want to live in many countries other than Japan.

INTVA 3. I want to work where people from other countries work.

INTVA 4. I'm interested in volunteering abroad.

INTVA 5. I don't think what's happening overseas has much to do with my daily life. (R)

INTVA 6. I'd rather avoid the kind of work that sends me overseas frequently. (R)

Interest in Foreign Affairs

IFA 1. I often watch world news on television or the Internet.

IFA 2. I often read about events in foreign countries in newspapers and books.

IFA 3. I often talk about world news with my family or friends.

IFA 4. I often hear about world news or events.

IFA 5. I often check on world news or events.

Note. Items with (R) are reverse scored. 